\title{
Relationship Between Chronic Pain and Sleep Quality in Patients with Temporomandibular Joint Dysfunction
}

\section{Temporomandibular Eklem Disfonksiyonu Olan Hastalarda Kronik Ağrı ve Uyku Kalitesi Illișkisi}

\author{
(1) Ömer Ekici
}

Afyonkarahisar Health Sciences University Faculty of Dentistry, Department of Oral and Maxillofacial Surgery, Afyonkarahisar, Turkey

\begin{abstract}
Objective: Craniofacial pain and sleep are interrelated: Pain can cause sleep problems, and sleep problems can worsen pain. This study aimed to establish the relationship between chronic pain and sleep quality among patients with temporomandibular disorders (TMDs).

Materials and Methods: The study was carried out in patients with TMDs who sought care at the oral and maxillofacial surgery clinic of a faculty of dentistry. This study included a total of 337 patients diagnosed with TMD according to the Research diagnostic criteria for TMDs. TMD pain was evaluated using the graded chronic pain scale, and their sleep quality was assessed with the Pittsburgh Sleep Quality index (PSQI).

Results: The mean PQQI index score of all participants was 6.54. No significant difference was found between the PSQI scores in terms of sociodemographic variables. The sleep quality of the participants varied significantly according to the pain levels. This difference was observed both in total sleep quality scores and in each of the seven components of sleep quality $(p<0.001$ and $p<0.005$, respectively). In this study, sleep disturbance components with the highest scores were "sleep disturbances $(1.5 \pm 0.65)^{\prime \prime}$, "sleep latency $(1.42 \pm 0.86)$ " and "subjective sleep quality $(1.21 \pm 0.68)$ ".

Conclusion: The findings of this study reveal that the quality of sleep decreased as the level of pain increased, that is, PSQI scores and all subcomponent scores are also increased. These findings indicate that physicians treating patients with TMD pain should investigate their quality of sleep.

Keywords: Orofacial pain, sleep quality, temporomandibular joint dysfunction
\end{abstract}

Öz

Amaç: Kraniyofasiyal ağrı ve uyku birbiriyle ilişkilidir: Ağrı uyku sorunlarına neden olabilir, uyku sorunları ağrıyı kötüleştirebilir. Bu çalışmanın amacı, temporo-mandibular eklem bozukluğu olan hastalarda kronik ağrı ile uyku kalitesi arasındaki ilişkiyi belirlemektir.

Gereç ve Yöntem: Çalışma bir diş hekimliği fakültesi ağız ve çene cerrahisi kliniğine tedavi için başvuran Temporomandibular bozukluk (TMD) hastaları ile gerçekleştirilmiştir. TMD'ler için araştırma tanı kriterlerine (ATK/TMD) göre TME bozukluğu tanısı alan 337 hasta çalışmaya dahil edildi. Hastaların TMD ağrıları Dereceli Kronik Ağrı ölçeği ile, uyku kaliteleri Pittsburgh Uyku Kalitesi indeksi (PUKI) ile değerlendirildi.

Bulgular: Tüm katılımcıların ortalama PUKI puanı 6,54 idi. Katılımcıların PUKi puanları arasında sosyodemografik değişkenler açısından anlamlı bir fark yoktu. Katılımcıların ağı düzeylerine göre uyku kaliteleri önemli derecede değiști. Bu fark hem toplam uyku kalitesi puanlarında hem de uyku kalitesinin 7 bileşeninin her birinde gözlendi (sırasıyla $p<0,001$ ve $\mathrm{p}<0,005$ ). Bu çalışmada, en yüksek uyku bozukluğu bileşenleri "uyku bozuklukları $(1,5 \pm 0,65)$ ", "uyku gecikmesi $(1,42 \pm 0,86)$ " ve "öznel uyku kalitesi $(1,21 \pm 0,68)^{\prime \prime}$ idi.

Sonuç: Çalışma bulgularına göre ağıı düzeyi arttıkça, uyku kalitesi azaldı yani toplam PUKI puanları ve tüm alt bileşen puanları yükseldi. Bu bulgular, TMD ağrısı olan hastaları tedavi eden hekimlerin uyku kalitelerini araştırması gerektiğini göstermektedir.

Anahtar Kelimeler: Orofasiyal ağrı, uyku kalitesi, temporomandibular eklem disfonksiyonu

\section{Introduction}

Pain and sleep disorders are the most prevalent issues in the population, so it is no wonder that these two situations overlap (1). Nevertheless, the relationship between pain and sleep is not one-way (2). Painful conditions interfere with sleep, but sleep disturbances often contribute to the perception of pain
(3). The bidirectional relationship is especially relevant when patients have chronic pain situations. Research indicates sleep problems in $50-89 \%$ of patients with any form of chronic pain (4). Patients with chronic pain frequently experience poor sleep quality (SQ), which may include impaired sleep onset or maintenance, as well as impaired sleep with repeated arousals, or a combination of these issues (5).

Address for Correspondence/Yazışma Adresi: Ömer Ekici MD, Afyonkarahisar Health Sciences University Faculty of Dentistry, Department of Oral and Maxillofacial Surgery, Afyonkarahisar, Turkey Phone: +90 5072179275 E-mail: dromerekici@hotmail.com ORCID-ID: orcid.org/0000-0002-7902-9601 Received/Geliş Tarihi: 18.11.2020 Accepted/Kabul Tarihi: 02.02.2021

${ }^{\circ}$ Copyright 2021 by Turkish Sleep Medicine Society / Journal of Turkish Sleep Medicine published by Galenos Publishing House. 
According to the American Academy of Orofacial Pain, temporo-mandibular disorders (TMDs) are described as a group of disorders including masticatory muscles, the temporomandibular joint (TMJ), and related structures (6). Typical clinical symptoms of TMD include idiopathic and episodic orofacial musculoskeletal pain and/or TMJ sounds (e.g. clicking, cracking, and crepitation) and/or restricted jaw movements (7). The etiology of TMD is complex, multifactorial, and coherent with the biopsychosocial model of the disease (8), and frequently present with jaw pain, headache, toothache, earache, facial pain or fullness or pressure on the face (9). TMDs are the main cause of non-dental orofacial pain. After chronic low back pain, the TMD is the second most prevalent musculoskeletal pain (10).

Patients with TMDs, particularly those with chronic pain, have often complained about sleep disorders (11-13). Up to $90 \%$ of patients with TMD usually experience poor SQ (14). Up to 70 percent of patients with TMD meet at least one criterion for a sleep disorder and 43 percent meet two or more criteria (15). In a recent systematic reviw study, it was reported that there is a relationship between painful TMD and $S Q$, and the presence of pain can strongly affect SQ in TMD patients (16). In chronic TMD patients, the relationship between chronic pain and sleep disturbances is not yet well known though substantial evidence exists (17). Assessing the quality of sleep can lead to successful therapies for many TMD patients. The objective of this study is therefore to establish the relationship between chronic pain and SQ among patients with TMD.

\section{Materials and Methods}

The study was carried out TMD patients who sought care at the Department of Oral and Maxillofacial Surgery Faculty of Dentistry in Afyonkarahisar Health Sciences University, from October 1, 2019, to April 30, 2020. This research was approved by the Ethics Committee of the Faculty of Medicine, Afyonkarahisar University of Health Sciences Turkey (2019/10317) and was conducted according to principles of the Declaration of Helsinki. Written informed consent was obtained from all patients. The clinical examination and diagnosis of TMD were made on the basis of the Research Diagnostic Criteria for TMD (RDC/TMD) (10). A single calibrated oral and maxillofacial surgeon examined all patients and conducted all questionnaires and tests to patients. TMD pain of patients was assessed with the Graded Chronic Pain scale (GCPS) and their SQ was assessed with the Pittsburgh Sleep Quality index (PSQI).

\section{GCPS}

Chronic pain was assessed using the GCPS as it was defined in the literatüre (18). GCPS has two indicators: Pain intensity and disability degree. Pain intensity determined by Visual Analog scales (VAS) (current pain intensity, maximum pain intensity, and average pain intensity in prior 6 months/3). Degree of disability, determined by quantifying the number of disability days and the degree of disability obtained from the sum of the VAS scores (how the disability affects patients' daily, recreational and work activities). The values are measured from 0 to 4 (grade 0: No pain in prior 6 months, grade I: Low intensity (pain intensity <50), low disability, grade II: High intensity (pain intensity $>50$ ), low disability, grade III: High disability, moderately limiting, grade IV: High disability, severely limiting).

\section{PSQI}

The PSQI is a short, easy-to-use questionnaire used to gather information on SQ. PSQI offers a combination of quantitative and qualitative sleep information (19). By the answers obtained from the person, seven components are evaluated: subjective quality of sleep, sleep latency, sleep duration, habitual sleep efficiency, sleep disturbances, use of sleeping medication, and daytime dysfunction (20). A point range from 0 to 3 is obtained for each component, with a higher score that indicates poorer $\mathrm{SQ}$. The questionnaire is scored from 0 to 21 points. If the total of the scores more five points, the patient has bad sleeping patterns or sleep disorders. Individuals can thus be graded as having the following: good sleep (0-4 scores), poor sleep (5-10 scores), and the occurrence of chronic sleep disturbance ( $>10$ scores).

\section{Statistical Analysis}

The data were analyzed with the Statistical Package for the Social Sciences (SPSS-version 22) program. Descriptive statistics was used for categorical variables and frequency calculations were expressed as percentage. Chi-square test was used for crosstabulations. One-Way ANOVA and Kruskal-Wallis test were used for comparison of mean values. The mean difference was considered significant at the 0.05 level.

\section{Results}

The sociodemographic characteristics and PSQI scores of patients with TMDs participating in the study are given in Table 1. The majority of the 337 participants (82.8\%) were women. When the age range of the participants was examined, the majority of the participants were young people and middle age group. Approximately half of the participants $(47.8 \%)$ were married. Only $8.6 \%$ of the participants had undergraduate and postgraduate education. When the Body Mass index (BMI) was examined, approximately half of the participants (52.2\%) were at normal weight, while $41.3 \%$ were overweight. The average PSQI index score of all participants was 6.54. Also, $76.3 \%$ of the participants had bruxism. There was no significant difference between the PSQI scores of the participants in terms of all sociodemographic variables (age, gender, marital status, education status, BMI, and bruxism).

In the study, patients' chronic pain states related to TMJ were evaluated using the GCPS. According to this assessment, $13.1 \%$ of patients had grade $0,33.5 \%$ had grade $1,43.6 \%$ had grade $2,9.8 \%$ had grade 3 pain. There was no participant with grade 4 pain rating. When SQ is evaluated using the PSQI, $43.6 \%$ of the participants had good SQ (0-5 points), $43.3 \%$ had poor SQ (6-10 points) and 13.1\% had chronic sleep disorder (11-21 points).

The relationship between the participants' chronic pain level and SQ is included in the cross chi square table (Table 2). In the 


\begin{tabular}{|c|c|c|c|c|}
\hline Demographic data & $n$ & $\%$ & \begin{tabular}{|l|} 
PSQI \\
Mean \pm SDs \\
\end{tabular} & $p$ \\
\hline \multicolumn{5}{|l|}{ Gender } \\
\hline Female & 279 & 82.8 & $6.65 \pm 3.47$ & \multirow{2}{*}{0.145} \\
\hline Male & 58 & 17.2 & $6.01 \pm 2.87$ & \\
\hline \multicolumn{5}{|l|}{ Age } \\
\hline$<20$ years old & 75 & 22.3 & $6.82 \pm 2.84$ & \multirow{5}{*}{0.061} \\
\hline $20-29$ years old & 99 & 29.4 & $5.95 \pm 1.97$ & \\
\hline $30-39$ years old & 83 & 24.6 & $6.27 \pm 3.91$ & \\
\hline 40-49 years old & 49 & 9.2 & $7.61 \pm 4.86$ & \\
\hline 50 and over age & 31 & 11.8 & $6.74 \pm 3.54$ & \\
\hline \multicolumn{5}{|l|}{ Marital status } \\
\hline Married & 161 & 47.8 & $6.67 \pm 3.55$ & \multirow{3}{*}{0.347} \\
\hline Single & 157 & 46.6 & $6.54 \pm 3.00$ & \\
\hline Divorced & 19 & 5.6 & $5.47 \pm 4.70$ & \\
\hline \multicolumn{5}{|l|}{ Education status } \\
\hline Primary school & 90 & 26.7 & $6.20 \pm 3.43$ & \multirow{5}{*}{0.175} \\
\hline Secondary school & 104 & 30.9 & $6.51 \pm 3.38$ & \\
\hline High school & 114 & 33.8 & $7.01 \pm 3.27$ & \\
\hline Faculty & 27 & 8 & $5.59 \pm 3.60$ & \\
\hline Graduate & 2 & 0.6 & $9.00 \pm 0.00$ & \\
\hline \multicolumn{5}{|l|}{ BMI } \\
\hline$<18.5 \mathrm{~kg} / \mathrm{m}^{2}$ (weak) & 22 & 6.5 & $5.54 \pm 2.50$ & \multirow{4}{*}{0.067} \\
\hline $18.5-24.9 \mathrm{~kg} / \mathrm{m}^{2}$ (normal) & 176 & 52.2 & $6.91 \pm 3.52$ & \\
\hline $25-29.9 \mathrm{~kg} / \mathrm{m}^{2}$ (overweight) & 106 & 31.5 & $5.96 \pm 2.98$ & \\
\hline$>30 \mathrm{~kg} / \mathrm{m}^{2}$ (obese) & 33 & 9.8 & $7.09 \pm 4.03$ & \\
\hline \multicolumn{5}{|l|}{ Bruxism } \\
\hline Yes & 257 & 76.3 & $6.67 \pm 3.40$ & \\
\hline No & 80 & 23.7 & $6.11 \pm 3.29$ & 0.181 \\
\hline Total & 337 & 100 & $6.54 \pm 3.38$ & \\
\hline
\end{tabular}

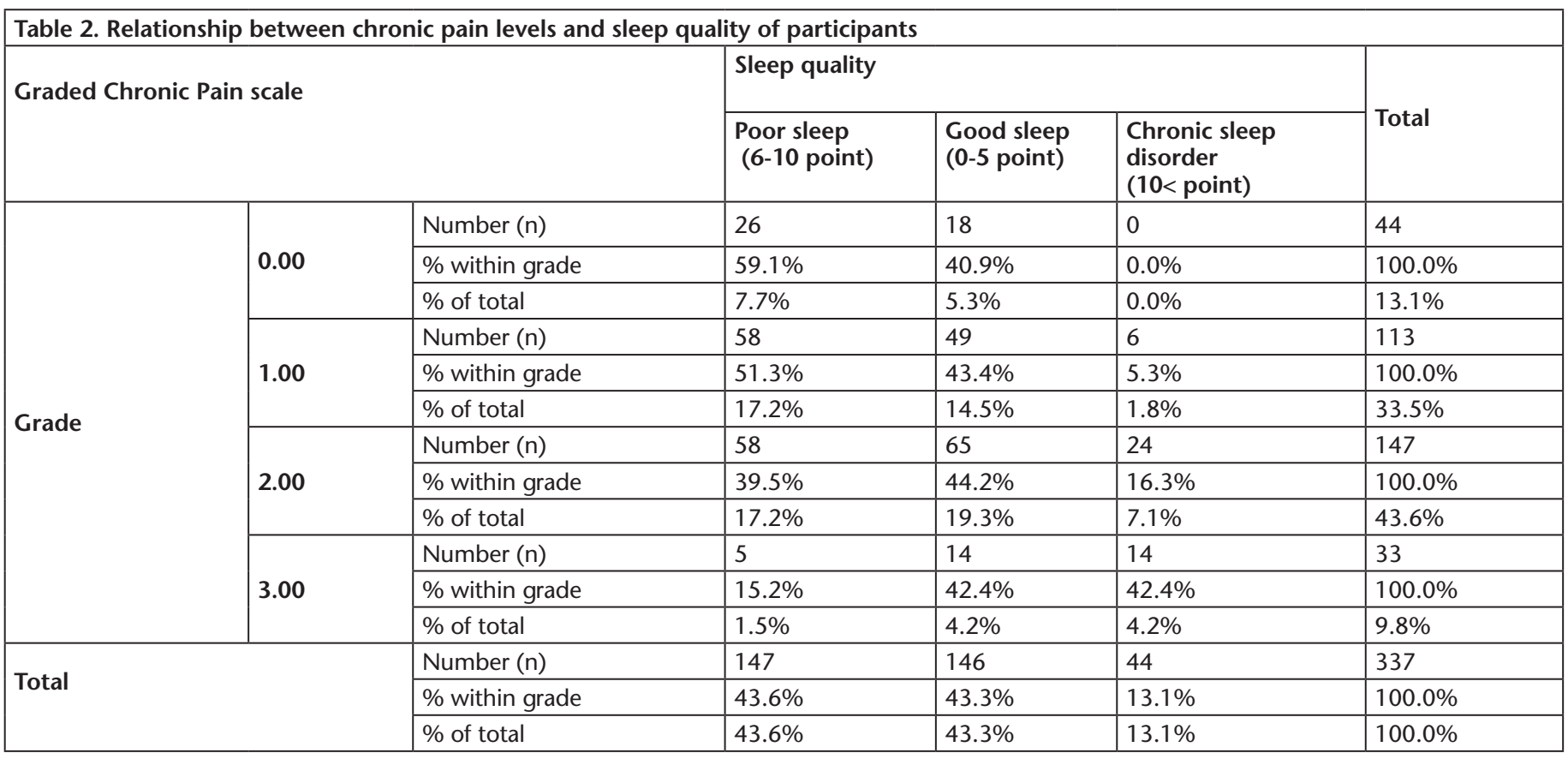


study, it was clearly seen that SQ deteriorated in parallel with the increase in the degree of pain of the participants. When Table 2 is examined, the rate of those who have good SQ is $59.1 \%$ in grade 0 , it decreases to $51.3 \%$ in grade $1,39.5 \%$ in grade 2 and $15.2 \%$ in grade 3 . Similarly, while there were no participants with chronic sleep disorders in grade 0 , the rate of those with chronic sleep disorders in grade 1 was 5.3\%, 16.3\% in grade 2 and $42.4 \%$ in grade 3.

Table 3 shows the average scores of the participants' SQ and SQ components. When PSQI SQ mean scores are examined, it is seen that the grade 0 group is 4.95 , the grade 1 group is 5.73 , the grade 2 group is 6.98 and the grade 3 group is 9.45 . According to ANOVA and Kruskall-Wallis tests, there was a significant difference between the participants' pain levels and SQ. This difference was observed both in total SQ scores and in each of the 7 components of SQ. As seen in Table 3, as the pain level increased, SQ decreased, that is, PSQI scores and all subcomponent scores also increased. In the present study, the highest scores in components of PSQI were "sleep disturbances $(1.5 \pm 0.65)$ ", "sleep latency $(1.42 \pm 0.86)$ ", and "subjective SQ $(1.21 \pm 0.68)^{\prime \prime}$.

\section{Discussion}

Adequate sleep is essential for healthy overall functioning. Poor sleep affects the perception of pain, too. Any painful condition will eventually interfere with sleep and affect mood, energy, etc. (21). The literature indicates a bidirectional correlation between pain and poor sleep (1). Poor sleep exacerbates pain, while greater pain ad-versely affects sleep (22). Sleep-wake patterns and quality of sleep can in a variety of ways affect orofacial pain (23). Pain-related awakening seen in approximately onethird of patients with craniofacial pain and is associated with severity of pain (24). This study investigated the association between chronic pain and SQ by using a chronic pain and sleep questionnaire in patients with TMJ disorders and by performing clinical examinations in a large number of patients.

Pain is a complicated experience that covers cognitive and emotional dimensions, which are perhaps the most common and disabling symptoms in medicine (25).
Although some evidence of this is available, the connection between chronic pain and sleep disturbance is not yet well explained. Chronic pain patients have poorer sleep than controls in terms of sleep duration, quality of sleep, and postsleep awakenings (26). Fifty to seventy percent of patients with chronic pain report sleep interruption, with most of these patients citing pain as the primary cause of sleep disruption (4). Approximately one-third of patients with chronic craniofacial pain and pain-related associations experience pain-related awakening (24). Seventy-seven percent of the orofacial pain population reported a decrease in SQ after their pain started (15). In an earlier PSG-based study comparing chronic-pain patients to healthy people, the chronic-pain group had more awakenings during the night than the control group. In addition, the chronic pain group reported substantially greater difficulty in beginning sleep than in the control group $(2,27)$. Fifty to seventy percent of chronic pain patients state that pain as the primary cause of sleep disruption (24).

TMD is a common musculoskeletal disease that affects $5-12 \%$ of the population and is frequently related to TMJ sounds, mandibular motion dysfunction, and pain in masticatory muscles and/or the preauricular region $(10,28)$. Pain is the main symptom for most TMDs and also the main reason patients seek treatment (29). TMD may follow a chronic course in the event of persistent or recurrent pain (30). In this study, $86.9 \%$ of the patients suffered from chronic pain associated with the TMJ. Like all chronic pain patients, TMD patients with chronic pain experience sleep deprivation $(31,32)$. Pain can also cause stress and anxiety and indirectly impair SQ. It has been reported that negative emotional states such as stress, anxiety, and depression can seriously impair SQ in TMD patients (33). Research has consistently shown that more than 50 percent of TMD patients experience poor SQ (17). Similar to the literature, $56.4 \%$ of TMD patients were found to have poor SQ. While the rate of patients with chronic sleep disorders was $13.1 \%$ in all patients, this rate was $42.4 \%$ in grade 3 group. In this study, there was a direct association between pain level and SQ. The increase in pain level caused a significant deterioration in all sub-components of SQ and total SQ. Especially in grade 3 patients, a significant deterioration was observed in both total

Table 3. Comparison of sleep quality according to chronic pain conditions of the participants

\begin{tabular}{|c|c|c|c|c|c|c|}
\hline & $\begin{array}{l}\text { Total } \\
(n=337)\end{array}$ & $\begin{array}{l}\text { Grade } 0 \\
(n=44)\end{array}$ & $\begin{array}{l}\text { Grade } 1 \\
(\mathrm{n}=113)\end{array}$ & $\begin{array}{l}\text { Grade } 2 \\
(\mathrm{n}=147)\end{array}$ & $\begin{array}{l}\text { Grade } 3 \\
(n=33)\end{array}$ & - \\
\hline PSQI & Mean \pm SDs & Mean \pm SDs & Mean \pm SDs & Mean \pm SDs & Mean \pm SDs & $\mathrm{p}$ \\
\hline 1. Subjective sleep quality & $1.21 \pm 0.68$ & $0.72 \pm 0.58^{\mathrm{a}}$ & $1.23 \pm 0.69^{b}$ & $1.27 \pm 0.62^{\mathrm{b}}$ & $1.48 \pm 0.75^{b}$ & 0.000 \\
\hline 2. Sleep latency & $1.42 \pm 0.86$ & $1.11 \pm 0.75^{\mathrm{a}}$ & $1.39 \pm 0.81^{\mathrm{ab}}$ & $1.42 \pm 0.93^{\mathrm{b}}$ & $1.90 \pm 0.67^{c}$ & 0.001 \\
\hline 3. Sleep duration & $0.57 \pm 0.91$ & $0.29 \pm 0.79^{\mathrm{a}}$ & $0.53 \pm 0.81^{\mathrm{ab}}$ & $0.59 \pm 0.88^{\mathrm{ab}}$ & $1.00 \pm 1.32^{\mathrm{b}}$ & 0.009 \\
\hline 4. Sleep efficiency & $0.61 \pm 0.83$ & $0.45 \pm 0.72^{\mathrm{a}}$ & $0.34 \pm 0.57^{a}$ & $0.73 \pm 0.87^{\mathrm{b}}$ & $1.24 \pm 1.03^{c}$ & 0.000 \\
\hline 6. Use of sleep medication & $0.18 \pm 0.57$ & $0.06 \pm 0.25^{\mathrm{a}}$ & $0.03 \pm 0.26^{\mathrm{a}}$ & $0.27 \pm 0.66^{b}$ & $0.45 \pm 0.97^{b}$ & 0.000 \\
\hline 7. Daytime dysfunction & $1.01 \pm 0.86$ & $0.90 \pm 0.93$ & $0.79 \pm 0.76$ & $1.06 \pm 0.83$ & $1.66 \pm 0.85$ & 0.000 \\
\hline PSQI global score & $6.54 \pm 3.38$ & $4.95 \pm 2.05^{\mathrm{a}}$ & $5.73 \pm 2.60^{\mathrm{a}}$ & $6.98 \pm 3.54^{\mathrm{b}}$ & $9.45 \pm 4.25^{c}$ & 0.000 \\
\hline
\end{tabular}

In each line, different superscripts indicate statistically significant difference between groups ( $<<0.005)$, PSQI: Pittsburgh Sleep Quality index, SDs: Standard deviations, In each line, different superscripts $(a, b, c)$ indicate statistically significant difference between groups $(p<0.005)$ 
SQ and all sub-components of SQ compared to other groups. It has been shown that insomnias related to chronic pain are frequently phenotypically similar to primary insomnia (34). Likewise, delayed sleep onset, disturbed sleep, frequent awakenings, and non-restorative sleep are the most common sleep-associated symptoms of pain sufferers (35). In patients with TMD, insomnia is the most common sleep disorder and changes in the severity of insomnia contribute to an increase in TMD pain (36). TMD patients normally do not wake from sleep, but pain-related waking has been documented by up to $24 \%$ of patients with a high muscle tenderness score (24). Myofascial pain patients registered substantially poorer sleep than controls and those with TMJ pain in TMDs (13). In the study of Sener and Güler, the PSQI components that were most affected by TMDs were subjective $S Q$, sleep latency, sleep disturbance, and habitual sleep efficiency (37). Similarly, sleep disturbance, sleep latency, and subjective SQ were the highest sleep disturbance components on the PSQI scale in this study.

\section{Study Limitations}

The main limitations of this study are related to its subjectivity because although a large number of patients were included, the results could be subjective, as the questionnaire was used instead of PSG. PSG is the gold standard for sleep architecture assessment and can be used to objectively diagnose sleep pathophysiology (38) but it is a rather expensive tool and applicable in small populations. Sleep-questionnaire-based research has the advantages of less time and less cost needed to collect data on their sleeping properties compared to PSG (39). Also, participants' habits such as bruxism were entirely based on their own self-reports. Sleep bruxism can be diagnosed through patient reports and clinical interviews, clinical examinations, intraoral appliances, or muscle activity recordings. According to the last international consensus, the diagnosis of bruxism made by self-report is classified as potential bruxism (40). The diagnosis of bruxism was made by a professional clinician on the basis of clinical diagnostic criteria for sleep bruxism, as defined by the American Academy of Sleep Medicine (41). Sleep laboratory evaluation is needed to establish a definitive diagnosis of sleep bruxism, but it is costly and inaccessible for large samples. This research is important in studying the quality of the sleep and the relationship with chronic pain by using a questionnaire and performing clinical examinations to a large number of TMJ patients.

\section{Conclusion}

The results of this study clearly revealed the relationship between TMJ chronic pain and sleep disorders. SQ is strongly associated with TMJ pain. TMD patients with chronic pain suffer from sleep deprivation like other chronic-pain patients. These results imply that clinicians treating patients with TMD should examine their SQ. Assessing SQ and disturbances should be part of the routine diagnostic workup for TMD patients with chronic pain. The management of patients with chronic TMD pain problems and sleep disturbances should be based on a systematic, multidisciplinary team plan that addresses all of the variables.

\section{Ethics}

Ethics Committee Approval: This research was approved by the Ethics Committee of the Faculty of Medicine, Afyonkarahisar Health Sciences University (2019/10-317) and was conducted according to principles of the Declaration of Helsinki.

Informed Consent: Written informed consent was obtained from all patients

Peer-review: Internally peer-reviewed.

Financial Disclosure: The author declared that this study received no financial support.

\section{References}

1. Finan PH, Goodin BR, Smith MT. The association of sleep and pain: An update and a path forward. J Pain 2013;14:1539-52.

2. Edwards RR, Grace E, Peterson S, Klick B, Haythornthwaite JA, Smith MT. Sleep continuity and architecture: Associations with pain-inhibitory processes in patients with temporomandibular joint disorder. Eur J Pain 2009;13:1043-7.

3. Moldofsky H. Sleep and pain. Sleep Med Rev 2001;5:385-96.

4. Cole JC, Dubois D, Kosinski M. Use of patient-reported sleep measures in clinical trials of pain treatment: a literature review and synthesis of current sleep measures and a conceptual model of sleep disturbance in pain. Clin Ther 2007;29(Suppl):2580-8.

5. LeBlanc M, Mérette C, Savard J, Ivers H, Baillargeon L, Morin CM. Incidence and risk factors in a population-based sample. Sleep 2009;32:1027-37.

6. Leeuw R de, Klasser GD, American Academy of Orofacial Pain. Orofacial pain : Guidelines for assessment, diagnosis, and management. $5^{\text {th }}$ ed. Batavia, Illnois: Quintessence Publishing Co; 2013.

7. Rener-Sitar K, Celebić A, Mehulić K, Petricević N. Factors related to oral health related quality of life in TMD patients. Coll Antropol 2013;37:407-13.

8. Slade $G D$, Fillingim $R B$, Sanders $A E$, Bair $E$, Greenspan JD, Ohrbach $R$, Dubnerz R, Diatchenko L, Smith SB, Knott C, Maixner W. Summary of findings from the OPPERA prospective cohort study of incidence of first-onset temporomandibular disorder: Implications and future directions. J Pain 2013;14(Suppl 12):T51-62.

9. Romero-Reyes M, Uyanik JM. Orofacial pain management: Current perspectives. J Pain Res 2014;7:99-115.

10. Schiffman E, Ohrbach R, Truelove E, Look J, Anderson G, Goulet JP, List T, Svensson P, Gonzalez Y, Lobbezoo F, Michelotti A, Brooks SL, Ceusters W, Drangsholt M, Ettlin D, Gaul C, Goldberg LJ, Haythornthwaite JA, Hollender L, Jensen R, John MT, De Laat A, Leeuw R, Maixner W, van der Meulen M, Murray GM, Nixdorf DR, Palla S, Petersson A, Pionchon P, Smith B, Visscher CM, Zakrzewska J, Dworkin SF, International RDC/TMD Consortium Network, International association for Dental Research; Orofacial Pain Special Interest Group, International Association for the Study of Pain. Diagnostic criteria for temporomandibular disorders (DC/TMD) for clinical and research applications: Recommendations of the International RDC/TMD Consortium Network* and Orofacial Pain Special Interest Group†. J Oral Facial Pain Headache 2014;28:6-27.

11. Sanders AE, Slade GD, Bair E, Fillingim RB, Knott C, Dubner R, Greenspan JD, Maixner W, Ohrbach R. General health status and incidence of first-onset temporomandibular disorder: The OPPERA prospective cohort study. J Pain 2013;14(Suppl 12):T51-62.

12. Karibe H, Goddard G, Shimazu K, Kato Y, Warita-Naoi S, Kawakami T. Comparison of self-reported pain intensity, sleeping difficulty, and 
treatment outcomes of patients with myofascial temporomandibular disorders by age group: A prospective outcome study. BMC Musculoskelet Disord 2014;15:423.

13. Lei J, Liu M-Q, Yap AUJ, Fu K-Y. Sleep disturbance and psychologic distress: Prevalence and risk indicators for temporomandibular disorders in a chinese population. J Oral Facial Pain Headache 2015;29:24-30.

14. Yatani H, Studts J, Cordova M, Carlson CR, Okeson JP. Comparison of sleep quality and clinical and psychologic characteristics in patients with temporomandibular disorders. J Orofac Pain 2002;16:221-8.

15. Riley JL, Benson MB, Gremillion HA, C D Myers, M E Robinson, Smith Jr CL, Waxenberg LB. Sleep disturbance in orofacial pain patients: pain-related or emotional distress? 2001;19:106-13.

16. Dreweck FDS, Soares S, Duarte I, Conti PCR, De Luca Canto G, Luís Porporatti A. Association between painful temporomandibular disorders and sleep quality: A systematic review. J Oral Rehabil 2020;47:1041-51.

17. Smith MT, Wickwire EM, Grace EG, Edwards RR, Buenaver LF, Peterson $S$, Klick B, Haythornthwaite JA. Sleep disorders and their association with laboratory pain sensitivity in temporomandibular joint disorder. Sleep 2009;32:779-90.

18. Von Korff M, Ormel J, Keefe FJ, Dworkin SF. Grading the severity of chronic pain. Pain 1992;50:133-49.

19. Buysse DJ, Reynolds CF, Monk TH, Berman SR, Kupfer DJ. The Pittsburgh sleep quality index: A new instrument for psychiatric practice and research. Psychiatry Res 1989;28:193-213.

20. De Leeuw R, Studts JL, Carlson CR. Fatigue and fatigue-related symptoms in an orofacial pain population. Oral Surg Oral Med Oral Pathol Oral Radiol Endod 2005;99:168-74.

21. Moldofsky H. Sleep and pain. Sleep Med Rev 2001;5:385-96.

22. Okifuji A, Hare BD. Do sleep disorders contribute to pain sensitivity? Curr Rheumatol Rep 2011;13:528-34.

23. Canivet $C$, Ostergren PO, Choi BK, Nilsson P, af Sillén U, Moghadassi $M$, Karasek R, Isacsson SO. Sleeping problems as a risk factor for subsequent musculoskeletal pain and the role of job strain: Results from a one-year follow-up of the Malmö shoulder neck study cohort. Int J Behav Med 2008; 15:254-62.

24. Benoliel R, Eliav E, Sharav Y. Self-reports of pain-related awakenings in persistent orofacial pain patients. J Orofac Pain 2009;23:330-8.

25. Schütz TCB, Andersen ML, Tufik $S$. The influence of orofacial pain on sleep pattern: A review of theory, animal models and future directions. Sleep Med 2009;10:822-8.

26. de Tommaso M, Delussi M, Vecchio E, Sciruicchio V, Invitto S, Livrea P. Sleep features and central sensitization symptoms in primary headache patients. J Headache Pain 2014;15:64.
27. Smith MT, Haythornthwaite JA. How do sleep disturbance and chronic pain inter-relate? Insights from the longitudinal and cognitivebehavioral clinical trials literature. Sleep Med Rev 2004;8:119-32.

28. Renton T, Durham J, Aggarwal VR. The classification and differential diagnosis of orofacial pain. Expert Rev Neurother 2012;12:569-76.

29. Laskin DM, Greene CS (Orthodontist), Hylander WL. Temporomandibular disorders: An evidence-based approach to diagnosis and treatment. Batavia,Illnois: Quintessence Pub; 2006.

30. Miettinen O, Lahti S, Sipilä K. Psychosocial aspects of temporomandibular disorders and oral health-related quality-of-life. Acta Odontol Scand 2012;70:331-6.

31. Sutton BC, Opp MR. Musculoskeletal sensitization and sleep: Chronic muscle pain fragments sleep of mice without altering its duration. Sleep 2014;37:505-13.

32. Maísa Soares G, Rizzatti-Barbosa CM. Chronicity factors of temporomandibular disorders: a critical review of the literature. Braz Oral Res 2015;29:1-6.

33. Ekici Ö. Association of stress, anxiety, and depression levels with sleep quality in patients with temporomandibular disorders. Cranio 2020:1-9.

34. Smith MT, Perlis ML, Smith MS, Giles DE, Carmody TP. Sleep quality and presleep arousal in chronic pain. J Behav Med 2000;23:1-13.

35. Davies KA, Macfarlane G], Nicholl BI, Dickens C, Morriss R, Ray $\mathrm{D}, \mathrm{McB}$ eth I. Restorative sleep predicts the resolution of chronic widespread pain: Results from the EPIFUND study. Rheumatology (Oxford) 2008;47:1809-13.

36. Quartana PJ, Wickwire EM, Klick B, Grace E, Smith MT. Naturalistic changes in insomnia symptoms and pain in temporomandibular joint disorder: A cross-lagged panel analysis. Pain 2010;149:325-31.

37. Sener S, Güler O. Self-reported data on sleep quality and psychologic characteristics in patients with myofascial pain and disc displacement versus asymptomatic controls. Int J Prosthodont 2012;25:348-52.

38. Blågestad T, Pallesen S, Lunde LH, Sivertsen B, Nordhus IH, Grønli J. Sleep in older chronic pain patients: A comparative polysomnographic study. Clin J Pain 2012;28:277-83.

39. Frisk U, Nordström G. Patients' sleep in an intensive care unit - Patients and nurses' perception. Intensive Crit Care Nurs 2003;19:342-9.

40. Lobbezoo F, Ahlberg J, Raphael KG, Wetselaar P, Glaros AG, Kato T, Santiago V, Winocur E, De Laat A, De Leeuw R, Koyano K, Lavigne G], Svensson P, Manfredini D. International consensus on the assessment of bruxism: Report of a work in progress. J Oral Rehabil 2018;45:837-44.

41. American Academy of Sleep Medicine.The international classification of sleep disorders : diagnostic \& coding manual. $2^{\text {nd }} \mathrm{ed}$. Westchester, IL: American Academy of Sleep Medicine: 2005. 